\title{
FAKTOR-FAKTOR BUDAYA ORGANISASI YANG MEMPENGARUHI KEMAMPUAN APARATUR PEMERINTAHAN NAGARI DALAM PENGELOLAAN KEUANGAN NAGARI
}

\author{
Mutia Reni \\ Jurusan Ilmu Administrasi Publik, Fakultas Ilmu Sosial, Universitas Negeri Padang \\ Email: mutiareni32@gmail.com
}

\begin{abstract}
The purpose of study was to analyze the influence of organizational culture on the performance of nagari government apparatus in managing nagari finance in Tanah Datar Regency.The background of this study was that there was still poor performance of nagari government apparatus in managing nagari financial in Tanah Datar Regency. This study used a quantitative approach with associative method. This study was conducted in 75 nagari government in Tanah Datar Regency with total population as many as 600 people consisted of walinagaries (village headmasters), nagari secretaries, nagari treasurers, and five head of nagari affairs. The sample in this study consisted of 244 respondents determined with Slovin formula. The data of this study were collected through questionnaires with Likert scale measurement. Data of this study were analyzed with Multiple Linear Regression test. The result of this study showed that organizational culture variable, both simultaneously and partially, significantly influenced the nagari financial management in Tanah Datar Regency.
\end{abstract}

Keywords: Organizational culture, job performance, nagari financial management

How to Cite: Mutia Reni. 2019. Faktor-faktor Budaya Organisasi yang Mempengaruhi Kemampuan Aparatur Pemerintahan Nagari dalam Pengelolaan Keuangan Nagari. 3(1): pp.47-60. DOI: https://doi. org/10.24036/jess/vol3-iss1

\section{Pendahuluan}

Undang-undang Nomor 32/2004 tentang pemerintahan daerah menjelaskan bahwa setiap APBD ditetapkan oleh perundang-undangan. Dijelaskan juga dalam undang-undang ini dimana setiap daerah diberikan kesempatan untuk mengelola pendapatan dan keuangan daerah sendiri-sendiri. Perihal ini bertujuan untuk meningkatkan kemandirian serta mempercepat laju pertumbuhan setiap daerah yang ada di indonesa. Kesempatan yang diberikan kepada pemerintahan daerh merupakan salah satu dari bentuk pelaksanaan sistem desentralisasi. Dimana desentralisasi bertujuan untuk mempercepat laju pertumbuhan serta mengharapkan adanya partisipasi masyarakat lokal disetiap daerah untuk ikut serta dalam memajukan dan mengembangkan daerahnya.

Sejak disahkannya UU No 6/2014 tantang desa, yang merupakan dasar dalam pemberian wewenang terhadap desa dalam mengelola potensi yang ada didaerahnya. Dalam undang-undang ini dituliskan bahwa desa memperoleh kesempatan yang luas untuk mengurus pemerintahannya sendiri serta mengelola 
proses keberlangsungan pembangunan daerahnya masing-masing yang bertujuan untuk meningkatkan taraf kehidupan masyarakat desa. Perihal ini juga dijelaskan dalam Peraturan Pemerintah Nomor 43/2014 yang membahas mengenai pengelolaan keuangan desa dimana dalam peraturan ini dijelaskan bahwa proses pengelolaan keuangan desa dimulai dari perencanaan, pelaksanaan, penatausahaan, pelaporan serta pertanggung jawaban. Pada peraturan ini dituliskan bahwa pemerintahan daerah mengalokasikan anggaran dana desa paling sedikit 10 persen dari dana perimbangan yang diberikan kepada kabupaten dari APBD setelah dikurangi dana alokasi khusus. selanjutnya dari dana yang diperoleh desa yang akan digunakan minimal 70 persen untuk pembiayaan pelaksanaan pemerintah desa, pembinaan masyarakat, pemberdayaan masyarakat, serta pemberdayaan masyarakat desa. selanjutnya, dari dana yang diterima oleh desa akan digunakan maksimal 30 persen untuk biaya operasional pemerintah desa, penghasilan dan tunjangan.

Selanjutnya mengenai pengelolaan keuangan desa ini juga diatur dalam PERMENDAGRI Nomor 113/2014 dalam peraturan ini dijelaskan bahwa pengelolaan keuangan desa di merupakan bentuk kegiatan yang terdiri dari perencanaan, pelaksanaan, pelaporan, dan pertanggung jawaban terhadap penggunaan dana yang diberikan kepada desa. Peraturan tersebut juga menjelaskan bahwa pengelolaan dana desa harus dikelola sesuai dengan asas-asas yang disebutkan dalam peraturan ini diantaranya yaitu; transparansi, akuntabilitas, partisipatif, dan dilaksanakan dengan tertib dan disiplin anggaran.

Selanjutnya, di Kabupaten Tanah Datar mengenai pengelolaan keuangan nagari diatur dengan Peraturan Bupati Tanah Datar Nomor 11/2014 yang menjelaskan bahwa keuangan nagari dikelola atas dasar peraturan perundangundangan dan dikatakan bahwa setiap belanja daerah yang diatasnamakan nagari harus memiliki bukti yang sah. Pengelolaan keuangan nagari seperti yang dijelaskan dalam peraturan ini dikelola dalam kurun waktu 1 tahun yang dihitung dari tanggal 1 Januari hingga 30 Desember atau sering disebut dengan tahun anggaran. Pada peraturan ini dapat dilihat bahwa pengelolaan keuangan nagari di Kabupaten Tanah Darat dikelola secara disiplin dan transparan selain itu setiap pengeluaran yang terjadi harus memiliki bukti yang sah. Namun pada kenyataannya masih ditemukan pelanggaran-pelanggaran atau penyimpangan mengenai pengelolaan keuangan nagari di Kabupaten Tanah Datar.

Salah satu bentuk penyimpangan yang terjadi adalah adanya walinagari pada salah satu kenagarian yang ada di Kabupaten Tanah Datar yang terbukti melakukan korupsi, yaitu Walinagari Limo Kaum yang melakukan korupsi dalam penggunaan dana reward lomba nagari berprestasi baik tingkat kabupaten, provinsi maupun nasional yang merugikan negara RP.94,2 Juta yang diungkapkan oleh Kepala Kejari Batu Sangkar M. Fatria di Batusangkar. Penyelewengan yang dilakukan oleh mantan Walinagari Limo Kaum telah melanggar Peraturan Bupati Tanah Datar mengenai pengelolaan keuangan daerah (Andika Wahyu,2016)

Selain itu melalui wawancara yang dilaksanakan pada hari Selasa, $15 \mathrm{Mei}$ 2018 dengan Walinagari Tigo Koto Kecamatan Rambatan mengatakan bahwa unsur-unsur walinagari terutama di Nagari Tigo Koto tidak adanya tupoksi yang jelas. Dimana tupoksinya telah ada namun mereka tidak bisa menjabarkan fungsi 
tersebut. Perangkat nagari sudah diberikan pembekalan dan lainnya, akan tetapi perangkat nagari yang ada tidak diberikan tugas dengan pekerjaan sesuai dengan yang dilatih tersebut. sehingga mengakitbatkan aparatur nagari tersebut tidak bisa bekerja dengan baik. Hal ini mengakibatkan perangkat nagari yang mampu bekerja hanya bendahara nagari, sehingga ketika terjadinya pertukaran bendahara, perangkat nagari yang ada tidak mampu bekerja sehingga karena kekurangan ilmu mereka harus belajar ke nagari tetangga. Disamping itu Kaur Perekonomian Nagari Padang Magek Kecamatan Rambatan dalam wawancara yang dilakukan pada tanggal yang sama mengatakan bahwa masih terdapat pengelompokpengelompokkan perangkat nagari dalam menyelesaikan pekerjaanya. Selain itu dalam melaksanakan pekerjaan pengelolaan keuangan nagari perangkat nagari pada umumnya tidak bekerja dengan kompak dan tidak solid.

Selain itu dilihat dari penelitian terdahulu yang penulis temukan terdapat penelitian yang menyatakan adanya pengaruh yang signifikan antara budaya organisasi terhadap kinerja. Dimana penelitian yang telah dilakukan oleh Baba (2012) yang melakukan penelitian Pengaruh Kompetensi, Komunikasi, dan Budaya Organisasi Terhadap Kinerja Karyawan (Studi kasus PT. Semen Bosowa Maros), Dimana dalam penelitian ini dikatakan bahwa budaya organisasi akan menciptakan latar belakang yang berhubungan dengan lingkungan, cara kerja, sikap, perilaku, dan pandangan karyawan terhadap organisasi dimana mereka berada. Hartidah \& Ludigdo (2010) yang melakukan penelitian terhadap Pengaruh Budaya Organisasi Terhadap Kinerja Auditor, dimana dari hasil penelitiannya ditemukan bahwa budaya organisasi memiliki dampak yang signifikan terhadap kinerja aouditor. Maabuat (2016) melakukan penelitian terhadap Pengaruh Kepemimpinan, Orientasi Kerja, Dan Budaya Organisasi Terhadap Kinerja Pegawai, yang menyatakan bahwa budaya organisasi jika diuji secara sendirisendiri menunjukkan bahwa tidak terdapat pengaruh yang signifikan terhadap kinerja pegawai di Dispenda Sulut UPTD Tondano.

Dari penjabaran masalah yang penulis paparkan di atas, penulis tertarik untuk menganalisis faktor-faktor budaya organisasi yang mempengaruhi kemampuan aparatur pemerintahan nagari dalam pengelolaan keuangan nagari di Kabupaten Tanah Datar. Penelitian ini merupakan intisari dari hasil penelitian skripsi dan merupakan bagian dari penelitian payung yang dilakukan oleh Syamsir (2017) dengan judul Model Pembinaan Aparatur Pemerintahan Nagari dalam Pengelolaan Keuangan Nagari di Kabupaten Tanah Datar. Rumusan masalah yang penulis kemukakan dalam penelitian ini sebagai berikut: Apakah terdapat pengaruh budaya organisasi secara simultan dan parsial terhadap kinerja aparatur nagari dalam pengelolaan keuangan nagari di Kabupaten Tanah Datar? Variabel budaya organisasi dalam penelitian ini terdiri dari enam sub variabel, yaitu: inovasi dan pengambilan resiko, orientasi hasil, orientasi orang, orientasi tim, keagresifan, dan kemantapan/stabilitas. 


\section{Tinjauan Kepustakaan}

\section{Konsep Kinerja dan Budaya Organisasi}

Menurut Pasolong (2010) Konsep kinerja bisa dilihat dari dua sisi yaitu kinerja pegawai yang merupakan hasil kerja anggota perorangan/indovidu dan kinerja organisasi yang merupakan kinerja totalitas hasil kerja yang hendak dicapai oleh suatu organisasi. Pendapat lainnya mengenai kinerja dikemukakan oleh Tsoner menyatakan kinerja merupakan perananan dari motivasi, kepandaian dan persepsi peranan. Sedangkan Bernardi dan Russel mengatakan kinerja merupakan pendataan mengenai hasil yang didapatkan dari fungsi pekerjaan atau kegiatan yang telah direncanakan dalam jangka waktu yang ditentukan. Selain itu Prawiro mengemukakan mengenai kinerja dimana ia mengatakan hasil kerja dapat diperoleh oleh indivitu maupun kelompok disebuah organisasi tertentu untuk meraih tujuan tertentu pada tenggang waktu yang ditentukan (dalam Pabundu, 2010). Selanjutnya Syamsir (2013) menemukan dua dimensi yang mempengaruhi kinerja individu; pertama, dimensi internal yang terdiri dari sifat individu, kemampuan, dan cara kerja. Selanjutnya adalah dimensi eksternal dimana terdiri atas lingkungan sosial contohnya kebiasaan, sikap, rekan kerja, bawahan atau atasan, fasilitas kerja dan iklim organisasi.

Selain itu menurut Syamsir (2009, 2014, dan 2015) dan Syamsir dan Ali Embi (2013), motivasi memiliki peran yang sangat penting bagi orang-orang yang bekerja disektor atau organisasi publik untuk mencapai tujuan organisasinya. Artinya pegawai yang memiliki motivasi tinggi merupakan salah satu faktor yang sangat mempengaruhi kinerja organisasi (Azhari dan Syamsir, 2012). Selanjutnya Syamsir (2016) mengemukakan bahwa umumnya teori-teori motivasi berasumsi bahwa motivasi sangat menentukan dan berpengaruh terhadap kinerja seseorang. Dengan demikian dapat dilihat bahwa motivasi kerja merupakan hal yang penting dalam meningkatkan kinerja pegawai, oleh karena itu pemimpin dalam organisasi harus mampu untuk memberikan motivasi terhadap anggota organisasi, salah satunya dengan menjaga stabilitas budaya organisasi. Karena budaya organisasi yang baik akan memberikan motivasi bagi anggota yang ada di dalam organisasi tertentu untuk bekerja dengan baik.

Selanjutnya konsep mengenai budaya organisasi, dimana setiap manusia kehidupannya selalu dikaitkan dengan budaya. Dimana didalamnya mencakup nilai-nilai, perilaku sosial, keyakinan-keyakinan tertentu yang pada akhirnya akan menciptakan apa yang disebut dengan budaya sosial atau budaya masyarakat. Begitupun dengan sebuah organisasi yang juga sangat dipengaruhi oleh budaya atau nilai-nilai yang pada akhirnya memberikan pengaruh terhadap bagaimana anggota kelompok mengambil suatu tindakan. Robbins (dalam Sopiah 2008) mengatakan budaya organisasi merujuk pada suatu sistem makna bersama yang dianut oleh setiap anggotanya dan yang membedakan antara satu organisasi dengan organisasi lainnya. Dalam sudut pandang pegawai dalam sebuah organisasi, budaya memberikan pedoman bagi pegawai mengenai segala sesuatu yang penting untuk dilakukan. 
Pengertian lainnya tentang budaya organisasi dijelaskan oleh Wiraman (2007) yang mengatakan bahwa budaya organisasi adalah nilai-nilai, norma, keyakinan, filsafat, kebiasaan organisasi, dan lainnya kemudian dipelihara dalam kurun waktu yang lama oleh pendiri organisasi orang-orang yang berada di dalam organisasi kemudian diturunkan kepada anggota kelompok dan diterapkan dalam setiap kegiatan organisasi yang pada akhirnya akan memberikan pengaruh terhadap cara berfikir, sikap, serta perilaku orang di dalam organisasi saat menghasilkan sesuatu, memberikan pelayanan, serta dalam pencapaian tujuan organisasi. Wheelen dan Hunger mengemukakan ada beberapa peran penting yang dimainkan oleh budaya perusahaan dalam sopiah (2008) dimana diantaranya yaitu;

1. Membantu dalam pengembangan rasa memiliki jati diri bagi pegawai

2. Mengembangkan keterkaitan pribadi dan organisasi dalam suatu perusahaan atau instansi

3. Membantu stabilitas organisasi sebagai sebuah sistem sosial

4. Menyediakan pedoman perilaku sebagai hasil dari norma perilaku yang telah di bentuk

Veithzal Rivai dan Deddy Mulyadi (2013) mengemukakan beberapa karakteristik budaya organisasi diantaranya yaitu;

1. Inovasi dan pengambilan resiko; dimana karyawan didorong untuk lebih berani dalam mengambil resiko dan bekerja secara inovatif

2. Perhatian; dimana anggota organisasi didorong untuk lebih teliti

3. Orientasi terhadap hasil

4. Orientasi terhadap orang

5. Berorientasi kepada tim

6. Keagresifan; melihat bagaimana anggota dalam oranisasi antusias dan berkompetisi dalam bekerja bukannya bersantai

7. Kemantapan; melihat sampai dimana setiap kegiatan organisasi mempertahankan status quo yang merupakan lawan tumbuhnya inovasi

Meskipun sebuah organisasi dapat menampilkan satu tipe budaya organisasi secara menonjol, ia tetap dapat menunjukkan keyakinan normatif dan karakteristik yang lain. Ada banyak penelitian yang telah dilakukan dalam melihat pengaruh budaya organisasi terhadap kinerja dalam sebuah organisasi. Dalam penelitian yang telah dilakukan ditemukan hasil yang mengatakan adanya pengaruh yang signifikan budaya organisasi terhadap kinerja seseorang atau kelompok. Temuan penelitian yang menyatakan adanya pengaruh yang signifikan diantaranya yaitu penelitian yang dilakukan oleh Indra Yudha (2018), Sudirjo \& Kristanto (2015), Faustyna (2015), Wales (2017), Baba, (2012), Hartidah \& Ludigdo (2010), Priagung (2016), Erni dalam Ismail (2012). Namun ada juga penelitian yang menemukan sebaliknya seperti yang dilakukan Maabuat (2016) menemukan bahwa budaya organisasi jika diuji secara parsial tidak berdampak signifikan pada kinerja. 


\section{Pengelolaan Keuangan Desa/Nagari}

Dalam Undang Undang Nomor 6 tahun 2014 pasal 71 ayat 1 dan 2 menjelaskan bahwa keuangan desa adalah semua hak dan kewajiban desa yang dapat dinilai dengan uang serta segala sesuatu berupa uang dan barang yang berhubungan dengan pelaksanaan hak dan kewajiban desa. Hak dan kewajiban tersebut akan menimbulkan pendapatan, belanja, pembiayaan, dan pengelolaan keuangan desa. Dengan adanya pernyataan tersebut maka kepala desa harus transparan dan bertanggungjawab mulai dari perencanaan, pelaksanaan, penatausahaan, pelaporan dan pertanggungjawaban keuangan desa. Semakin berkembangnya pengetahuan masyarakat suatu desa untuk mengetahui penggunaan dana yang masuk ke dalam desa, membuat aparatur desa harus siap untuk memaparkan secara transaparan dan bertanggung jawab mengenai perencanaan, pelaksanaan, penatausahaan, pelaporan dan pertanggungjawaban dana yang diterimanya (dalam Henri: 2017)

Murtiono mengungkapkan bahwa pengelolaan keuangan desa harus mengacu pada prinsip atau asas yang telah dijelaskan di dalam Peraturan KEMENDAGRI Nomor 113/2014, dimana diantaranya yaitu;

1. Transparansi; merupakan keterbukaan yang diberikan kepada masyarakat sehingga memperoleh akses untuk mengetahui informasi tentang pengelolaan keuangan desa.

2. Akuntabel; prinsip seseorang dalam mempertanggungjawabkan segala sesuatu mengenai pengelolaan demi mencapai tujuan yang telah ditentukan

3. Partisipatif; merupakan keterlibatan masyarakat pada semua proses pengelolaan keuangan

4. Tertib dan Disiplin Anggaran; merupakan pengelolaan yang tepat waktu, tepat guna serta didukung dengan bukti-bukti administrasi yang akurat dan dapat dipertanggungjawabkan selain itu berpedoman pada peraturan yang berlaku

Peraturan Mentri Dalam Negri No 113 Tahun 2014 menjelaskan bahwa pengelolaan keuangan desa di kelola oleh kepala desa yang mewakili pemerintahan desa dalam kepemilikan kekayaan milik desa yang dipisahkan. Untuk terciptanya pengelolaan keuangan yang baik maka pengelolaan keuangan desa dikelola berdasarkan azas transparan, akuntabel, partisipatif, serta dilakukan dengan tertib dan disiplin anggaran.

Selanjutnya mengenai pengelolaan keuangan nagari di Kabupaten Tanah Datar dijelaskan dalam Peraturan Bupati No 11/2014. Dalam peraturan ini disebutkan bahwa pengelolaan keuangan nagari dilaksanakan dalam jangka waktu 1 tahun yang terhitung dari 1 Januari hingga 31 Desember. Dalam pemerintahan nagari dana nagari diperoleh dari APBN yang tujukan untuk nagari, dan nantinya akan dipakai untuk pembiayaan pelaksanaan pemerintah, pembangunan, pemberdayaan masyarakat serta pembinaan masyarakat.

Selain itu Puji Agus mengatakan bahwa pengelolaan keuangan desa atau setingkat dengan nagari adalah semua yang mencakup perencanaan, pelaksanaan, penatausahaan, pelaporan dan pertanggungjawaban keuangan desa. dimana pelaksanaan kewenangan yang didasarkan atas hak asal usul serta kewenangan 
desa dalam skala lokal akan dibiayai dari APBD Desa. Selain itu pendanaan kewenangan berskala lokal juga bisa dialokasikan dari APBN dan APBD. Untuk mengukur kinerja perangkat nagari Murtiono juga mengemukakan beberapa indikator yang sejalan dengan PERMENDAGRI No 133/2014 dimana diantaranya yaitu transparansi, akuntabel, partisipatif, tertib dan disiplin anggaran.

Pengelolaan keuangan nagari di Kabupaten Tanah Datar dikelola oleh Walinagari seperti yang dijelaskan dalam Peraturan Nagari Nomor 4/2008 bahwa Pemerintahan Nagari merupakan Walinagari serta unsur-unsur dalam pemerintahan nagari termasuk bendahara dan sekretaris nagari. Dalam peraturan nagari Kabupaten Tanah Datar dijelaskan mengenai tugas dan fungsi perangkat nagari yang merupakan unsur yang membantu walinagari dalam menjalankan tugasnya. Dalam peraturan ini juga disebutkan sekretaris nagari memeliki fungsi untuk membantu melaksanakan tugas walinagari yang terkait dengan urusan pemerintahan, pembangunan serta kemasyarakatan. Selain hal tersebut akan melaksanakan tugas dan fungsi walinagari jika berhalangan hadir. Sedangkan bagian urusan lainnya bertugas untuk melaksanakan kegiatan administrasi dan memberikan pelayanan terhadap masyarakat berdasarkan bidang masing-masing dan akan bertanggung jawab terhadap walinagari melalui sekretaris nagari.

Hal ini sama dengan yang dijelaskan dalam PERMENDAGRI 113/2014 yang menyebutkan bahwa kepala desa memiliki kewenangan untuk membuat peraturan mengenai pelaksanaan APBD Desa, membuat Pelaksanaan Teknis Pengelolaan Keuangan Desa, menentukan petugas yang melaksanakan pemungutan pendapatan desa, mengesahkan pengeluaran sesuai yang telah ditentukan didalam APBD Desa.

\section{Metode Penelitian}

Pada penelitian ini peneliti menggunakan pendekatan kuantitatif. Penelitian telah dilakukan dibeberapa nagari di Kabupaten Tanah Datar selama kurang lebih 3 bulan. Populasi dalam penelitian ini sebanyak 600 responden dengan jumlah nagari sebanyak 75 nagari yang terdiri dari seluruh aparatur nagari di Kabupaten Tanah Datar. Sedangkan untuk sampel yang digunakan sebanyak 244 responden yang dihitung menggunakan rumus Slovin. Untuk pengambilan sampel menggunakan teknik Multistage Random Sampling yang merupakan pengambilan sampel dari populasi yang dilakukan secara bertingkat dan didasarkan atas pembagian wilayah kerja pada suatu pemerintahan.

Pengumpulan data pada penelitian ini dilakukan dengan penyebaran kuesioner dengan pengukuran skala Likert dengan empat opsi, yaitu: Sangat Setuju, Setuju, Tidak Setuju, Sangat Tidak Setuju. Kemudian untuk memperoleh gambaran umum dari kedua variabel digunakan Frekuensi, Mean, dan TCR. Untuk melihat kategori TCR digunakan pendapat Hadi, 2004 dimana jawaban responden pada rentang $81 \%-100 \%$ dikategorikan sangat tinggi, $61 \%-80 \%$ dikategorikan tinggi, 41\%-60\% cukup atau sedang, 21\%-40\% rendah, 00\%-20\% sangat rendah. Teknik analisis data dalam penelitian ini menggunakan uji regresi linear berganda. 


\section{Hasil Penelitian dan Pembahasan}

Secara umum hasil penelitian menunjukkan nilai rata-rata TCR variabel budaya organisasi dapat dilihat pada tabel 1 di bawah ini:

Tabel 1. Deskripsi Variabel Budaya Organisasi

\begin{tabular}{|c|c|c|c|c|}
\hline \multirow[t]{2}{*}{ Variabel } & \multirow[t]{2}{*}{ Mean } & \multirow[t]{2}{*}{ Mean/TCR } & \multicolumn{2}{|c|}{$\begin{array}{l}\text { Kategori Mean } \\
\text { Responden }\end{array}$} \\
\hline & & & Tinggi & Rendah \\
\hline Pengambilan Resiko & 244 & $3,07 / 76,74 \%$ & $33 / 14 \%$ & $211 / 86 \%$ \\
\hline Inovasi & 244 & $3,03 / 75,82 \%$ & $38 / 16 \%$ & $206 / 84 \%$ \\
\hline Orientasi Hasil & 244 & $3,16 / 78,89 \%$ & $49 / 20 \%$ & $195 / 80 \%$ \\
\hline Orientasi Orang & 244 & $3,10 / 77,56 \%$ & $35 / 14 \%$ & $209 / 86 \%$ \\
\hline Orientasi Tim & 244 & $2,93 / 73,16 \%$ & $210 / 86 \%$ & $34 / 14 \%$ \\
\hline Keagresifan & 244 & $2,65 / 66,29 \%$ & $144 / 59 \%$ & $100 / 41 \%$ \\
\hline Kemantapan/Stabilitas & 244 & $2,74 / 68,55 \%$ & $168 / 69 \%$ & $76 / 31 \%$ \\
\hline $\begin{array}{l}\text { Rata-Rata Variabel } \\
\text { Budaya Organisasi }\end{array}$ & 244 & $2,95 / 73,86 \%$ & $137 / 56 \%$ & $107 / 44 \%$ \\
\hline
\end{tabular}

Dari Tabel 1 di atas dapat dilihat rata-rata budaya organisasi aparatur nagari berada dikategori "Tinggi" $(73,86 \%)$. Jika dilihat secara rinci, dapat dijelaskan bahwa aspek pengambilan resiko aparatur nagari berada pada kategori "Tinggi" $(76,74 \%)$. pada aspek inovasi aparatur nagari juga berada pada kategori "Tinggi" (75,82\%). Aspek orientasi hasil juga berada pada kategori "Tinggi" (78,89\%). Kemudian aspek orientasi orang juga berada pada kategori "Tinggi" $(77,56)$. Pada aspek orientasi tim juga berada pada kateori "Tinggi" $(73,16 \%)$. Aspek keagresifan yang juga pada kategori "Tinggi" (66,29\%), dan aspek stabilitas atau kemantapan yang juga berada pada kategori "Tinggi" (68,55\%). Selanjutnya jika dilihat dari kategori mean responden budaya organisasi yang berada dibawah rata-rata (mean) lebih kecil persentasenya di bandingkan dengan budaya organisasi yang berada di atas rata-rata (mean) dengan perbandingan $44 \%$ : 56\%. Sehingga dapat disimpulkan bahwa budaya organisasi aparatur nagari di Kabupaten Tanah Datar berada pada kategori sedang/cukup.

Tabel 2. Deskripsi Variabel Pengelolaan Keuangan Nagari

\begin{tabular}{lcclc}
\hline Item Pernyataan & $\mathbf{N}$ & Mean/TCR & \multicolumn{2}{l}{ Kategori Mean Responden } \\
\cline { 4 - 5 } & & & Tinggi & Rendah \\
\hline Transparansi & 244 & $3,20 / 79,96 \%$ & $87 / 36 \%$ & $157 / 64 \%$ \\
$\begin{array}{l}\text { Akuntabilitas } \\
\text { Partisipasi }\end{array}$ & 244 & $3,29 / 82,35 \%$ & $100 / 41 \%$ & $144 / 59 \%$ \\
$\begin{array}{l}\text { Disiplin dan tertib anggaran } \\
\text { Rata-rata variabel } \\
\text { pengelolaan keuangan } \\
\text { nagari }\end{array}$ & 244 & $3,25 / 81,30 \%$ & $97 / 40 \%$ & $147 / 60 \%$ \\
\hline
\end{tabular}


Dari tabel di atas bahwa rata-rata kinerja pengelolaan keuangan nagari berada pada kategori "Tinggi" (81,65\%). Jika dilihat secara rinci maka aspek transparansi dikategorikan "Tinggi" (79,96\%), aspek akuntabilitas dikategorikan "Sangat Tinggi" (82,35\%), aspek partisipasi juga dikategorikan "Tinggi" $(81,30 \%)$, dan aspek disiplin dan tertib anggran juga dikategorikan "Sangat Tinggi" (83,22\%). Selanjutnya jika dilihat dari kategori mean responden, dapat dilihat bahwa persentase kinerja pengelolaan keuangan dibawah rata-rata lebih besar dibandingkan persentase rata-rata kinerja pengelolaan keuangan di atas rata-rata. Sehingga dapat disimpulkan bahwa kinerja pengelolaan keuangan nagari di Kabupaten Tanah Datar masih tergolong sedang.

Selanjutnya uji regresi linear berganda dilakukan untuk melihat apakah terdapat pengaruh budaya organisasi terhadap kinerja aparatur nagari dalam pengelolaan keuangan nagari di Kabupaten Tanah Datar. Hasil uji tersebut dapat dilihat pada tabel 3 di bawah ini.

Tabel 3. Pengaruh variabel budaya organisasi (secara simultan) terhadap kinerja perangkat nagari dalam pengelolaan keuangan

\begin{tabular}{lccccc}
\multicolumn{8}{c}{ Model Summary $^{\mathbf{b}}$} \\
\hline Model & $\mathrm{R}$ & R Square & $\begin{array}{c}\text { Adjusted R } \\
\text { Square }\end{array}$ & $\begin{array}{c}\text { Std. Error of the } \\
\text { Estimate }\end{array}$ & Durbin-Watson \\
\hline 1 & $.503^{\mathrm{a}}$ & .253 & .231 & .30600 & 1.777 \\
\hline
\end{tabular}

a. Predictors: (Constant), Kemantapan/Stabilitas, Pengambilan Resiko, Orientasi Orang, Keagresifan, Orientasi Hasil, Inovasi, Orientasi Tim

b. Dependent Variable: Rata-Rata Pengelolaan Keuangan

Tabel 4. Hasil uji Anova (F) pengaruh variabel budaya organisasi terhadap kinerja perangkat nagari dalam pengelolaan keuangan nagari

\begin{tabular}{llccccc}
\hline \multicolumn{6}{c}{ ANOVA $^{\mathbf{b}}$} \\
Model & & Sum of Squares & Df & Mean Square & F & Sig. \\
\hline 1 & Regression & 7.482 & 7 & 1.069 & 11.415 & $.000^{\mathrm{a}}$ \\
& Residual & 22.098 & 236 & .094 & & \\
& Total & 29.581 & 243 & & & \\
\hline
\end{tabular}

\footnotetext{
a. Predictors: (Constant), Kemantapan/Stabilitas, Pengambilan Resiko, Orientasi Orang, Keagresifan, Orientasi Hasil, Inovasi, Orientasi Tim

b. Dependent Variable: Rata-Rata Pengelolaan Keuangan
}

Dari Tabel 3 di atas dapat dijelaskan bahwa Adjusted $R$ Square dari hasil analisis uji regresi adalah 0,231. Dengan demikian bisa disimpulkan bahwa besarnya pengaruh budaya organisasi dengan variabel inovasi dan pengambilan resiko, 
orientasi hasil, orientasi orang, orientasi tim, keagresifan, dan kemantapan/stabilitas terhadap kinerja aparatur nagari dalam pengelolaan keuangan nagari sebesar 23,1\%. Selebihnya sebesar 76,9\% dipengaruhi oleh variabel lain di luar peneltian ini. Sementara itu jika dilihat dari hasil analisis uji Anova didapatkan bahwa nilai signifikansi diperoleh angka $0,000^{\mathrm{a}}$ yang berarti bahwa kebenaran dari hasil uji regresi ini dapat dipercaya hingga 100\%.

Selanjutnya, untuk menjawab rumusan masalah lainnya yang ingin dijawab diantaranya yaitu, apakah terdapat pengaruh inovasi dan pengambilan resiko, orientasi hasil, orientasi orang, orientasi tim, keagresifan, kemantapan/stabilitas dapat dilihat pada Tabel 5 yang disajikan di bawah ini.

Tabel 5. Pengaruh variabel inovasi dan pengambilan resiko, orientasi hasil, orientasi tim, keagresifan, dan kemantapan/stabilitas secara sendirisendiri terhadap pengelolaan keuangan nagari

\begin{tabular}{llccc}
\hline \multicolumn{1}{c}{ Variabel } & R & R Square & $\begin{array}{c}\text { Adjusted R } \\
\text { Square }\end{array}$ & Sig. \\
\hline Pengambilan resiko & $.293^{\mathrm{a}}$ & .086 & .082 & $.000^{\mathrm{b}}$ \\
Inovasi & $.307^{\mathrm{a}}$ & .094 & .090 & $.000^{\mathrm{b}}$ \\
Orientasi hasil & $.446^{\mathrm{a}}$ & .199 & .196 & $.000^{\mathrm{b}}$ \\
Orientasi orang & $.301^{\mathrm{a}}$ & .091 & .087 & $.000^{\mathrm{b}}$ \\
Orientasi tim & $.216^{\mathrm{a}}$ & .046 & .043 & $.001^{\mathrm{b}}$ \\
Keagresifan & $.232^{\mathrm{a}}$ & .054 & .050 & $.000^{\mathrm{b}}$ \\
Kemantapan/stabilitas & $.294^{\mathrm{a}}$ & .086 & .083 & $.000^{\mathrm{b}}$ \\
\hline
\end{tabular}

Untuk menjawab rumusan masalah di atas dapat dilihat pada tabel 5, dimana sub-variabel pengambilan resiko memiliki pengaruh terhadap kinerja aparatur nagari dalam pengelolaan keuangan nagari sebesar $8,2 \%$, sub variabel inovasi $9 \%$, sub variabel orientasi hasil 19,6\%, sub variabel orientasi orang $8,7 \%$, orientasi tim 4,3\%, keagresifan 5\% dan kemantapan/stabilitas 8,3\%. Jika dilihat dari nilai signifikansi menunjukkan angka 0,000 dan 0,001 yang berarti bahwa kesimpulan dari hasil penelitian ini dapat dipercaya hingga $100 \%$.

\section{Pembahasan}

Hasil penelitian yang diperoleh dalam penelitian ini dapat disimpulkan bahwa penelitian ini ikut memperkuat dan mendukung teori yang telah ada. Seperti teori yang dikemukakan oleh Wiraman (2007) dimana ia menyatakan bahwa budaya organisasi merupakan nilai, norma, keyakinan, filsafat, kebiasaan organisasi, dan sebagainya yang dipertahankan dalam jangka waktu yang lama oleh pendiri dan anggota-anggota kelompok di dalam organisasi, yang kemudian akan diturunkan dan diajarkan pada anggota baru dalam organisasi yang kemudian diterapkan pada setiap kegiatan organisasi yang pada akhirnya memberikan pengaruh pada cara berfikir, sikap, dan perilaku anggota organisasi dalam memproduksi produk, memberikan pelayanan, dan mencapai tujuan organisasi. 
Penelitian ini juga memperkuat hasil penelitian yang dilakukan oleh beberapa peneliti lainnya diantaranya, Mariam (dalam Wales et al., 2017) yang menemukan bahwa budaya organisasi dan kepemimpinan secara bersama-sama memberikan dampak yang signifikan terhadap kinerja karyawan. Faustyna (2015) juga menemukan bahwa budaya organisasi dan dan etos kerja menjadi salah satu faktor yang mempengaruhi kinerja. Dikatakan dalam penelitian ini budaya organisasi dan etos kerja secara bersama-sama berdampak positif terhadap kinerja pegawai. Dengan demikian jika budaya organisasi dan etos kerja pada suatu organisasi rendah maka kinerja pegawai di organisasi tersebut juga akan berbanding sama. Selanjutnya penelitian yang dilakukan Sudirjo \& Kristanto (2015) yang juga mengemukakan bahwa budaya organisasi, kepemimpinan, dan kepuasan kerja memberikan dampak yang signifikan terhadap kinerja pegawai. Dimana temuan pada penelitian ini mengatakan penurunan budaya organisasi, kepemimpinan, dan kepuasan kerja, komitmen organisasional merupakan penyebab terjadinya kinerja karyawan yang rendah. Baba (2012) juga menemukan bahwa budaya organisasi memberikan pengaruh yang positif terhadap kinerja karyawan. Wales (2017) dan Indra Yudha (2018) juga menemukan bahwa kinerja karyawan dipengaruhi oleh kepuasan kerja dan budaya organisasi. Selanjutnya penelitian yang dilakukan oleh Hartidah \& Ludigdo (2010) yang menemukan bahwa budaya organisasi hanya memberikan pengaruh terhadap variabel individual. Selanjutnya Priagung (2016) yang menemukan bahwa budaya organisasi memiliki pengaruh terhadap kinerja keuangan organisasi publik. Dimana dalam penelitian ini dikatakan bahwa budaya organisasi mengikat karyawan yang bekerja di dalamnya untuk berperilaku sesuai budaya yang ada di dalamnya

\section{Penutup}

Hasil penelitian dan pembahasan yang telah dikemukakan di atas dapat disimpulkan bahwa: variabel-variabel budaya organisasi berada pada kategori sedang atau cukup sedangkan untuk variabel pengelolaan keuangan nagari juga berada pada kategori sedang. Sedangkan untuk pengaruh budaya organisasi terhadap kinerja aparatur nagari dalam pengelolaan keuangan nagari di Kabupaten Tanah Datar menunjukkan bahwa terdapat pengaruh yang signifikan baik secara simultan maupun parsial

Selanjutnya dari hasil pembahasan serta kesimpulan yang telah dipaparkan di atas penulis dapat memberikan masukan atau saran diantaranya yaitu;

1. Disarankan untuk lebih meningkatkan budaya organisasi, serta menjaga dan menciptakan budaya organisasi yang baik untuk meningkatkan kinerja aparatur nagari dalam pengelolaan keuangan nagari di Kabupaten Tanah Datar.

2. Dengan dilakukannya penelitian ini diharapkan bisa membantu peneliti lainnya yang akan melakukan penelitian untuk melihat gambaran mengenai pengaruh budaya organisasi terhadap kinerja pengelolaan keuangan nagari terutama di Kabupaten Tanah Datar. 


\section{DAFTAR KEPUSTAKAAN}

\section{Sumber Buku}

Nurdin, Ismail. 2012. Budaya Organisasi Konsep,Teori Dan Implementasi. Malang. Universitas Brawijaya Press (UB Press)

Pasolong, Herbani. 2010. Teori Administrasi Negara. Bandung. Alfabeta

Rivai, Veithzal dan Deddy Mulyadi. 2013. Kepemimpinan Dan Perilaku Organisasi. Jakarta. PT. RajaGrafindo Persada

Sopiah.2008. Perilaku Organisasi. Yogyakarta. C.V Andi.

Wiraman. 2007. Budaya Dan Iklim Organisasi Teori Aplikasi Dan Penelitian. Jakarta Salemba Empat

\section{Sumber Jurnal}

Baba, A. (2012). Pengaruh Kompetensi , Komunikasi Dan Budaya Organisasi Terhadap Kinerja Karyawan Pt. Semen Bosoma Maros. Ekuitas: Jurnal Ekonomi Dan Keuangan, 18(80), 524-540.

Faustyna. (2015). Pengaruh Budaya Organsasi Dan Etos Kerja Terhadap Kinerja Karyawan Pada Bpjs Ketenagakerjaan Cabang Belawan. Akuntansi Dan Bisnis, 1, 11-25.

Hartidah, A. D., \& Ludigdo, U. (2010). Pengaruh Budaya Organisasi Terhadap Kinerja Auditor Pada Kantor Akuntan Publik Di Malang Dan Surabaya. Jurnal Akuntansi Multiparadigma, 1(2), 239-253.

Indra Yudha, R. (2018). Pengaruh Budaya Organisasi dan Kepuasan Kerja Terhadap Kinerja Karyawan pada PT. Jaya Abadi Sumber Pasifik Kota Jambi. Manajemen Dan Kewirausahaan, 9(2), 24-35.

Maabuat, E. S. (2016). Pengaruh Kepemimpinan, Orientasi Kerja, Dan Budaya Organisasi Terhadap Kinerja Pegawai (Studi Pada Dispenda Sulut Uptd Tondano). Jurnal Berkala Ilmiah Efisiensi, 16(01), 219-231.

Priagung, D. E. (2016). Pengaruh Penyerapan Anggaran , Budaya Organisasi , Kepuasan Kerja Dan Pengawasan Inspektorat Terhadap Kinerja Keuangan Organisasi Publik ( Studi pada Pemerintah Daerah Kabupaten Banjarnegara). Jurnal Ekonomi Dan Bisnis Islam, 2(1), 1-15. https://doi.org/10.1007/s00412-007-0104-X

Sudirjo, F., \& Kristanto, T. (2015). Pengaruh Budaya Organisasi, Gaya Kepemimpinan Dan Kepuasan Kerja Terhadap Kinerja Karyawan Dengan Komitmen Organisasional Sebagai Variabel Interverning. Serat Acitya Jurnal Ilmiah, 4, 1-16. 
Syamsir. (2017)."Model Pembinaan Kapasitas Aparatur Pemerintah Nagari Dalam Pengelolaan Keuangan Nagari Di Kabupaten Tanah Datar Provinsi Sumatera Barat ". Laporan Penelitian. Padang . Universitas Negeri Padang

Wales, G. V., Mandey, S. L., \& Wenas33, R. S. (2017). Pengaruh Budaya Organisasi, Gaya Kepemimpinan, Dan Disiplin Kerja Terhadap Kinerja Karyawan Pt. Bank Tabungan Negara (Persero) Tbk. Kantor Cabang Manado. Jurnal EMBA, 5, 4435-4444. https://doi.org/10.1063/1.857651

Rozanti, T dan Sayamsir. 2018. The Influence of Knowledge and Attitude on The Performance of Nagari Apparatus in Nagari Financial Management in Sungai Tarab, Tanah Datar. Conference Proceedings CelSciTech-UMRI 2018.(3).

S Syamsir. 2016. The Influence Of Public Service Motivation On Service Quality Of Civil Servants In West Sumatra Indonesia. European Jurnal Of Economics and Busines Studies 2(2), 133-142.

Syamsir dan Ali-Embi, M. (2013). Ideologi Politik dan Motivasi Pelayanan Publik di Kalangan PNS Kota Padang. TINGKAP, 9(1), 67-82. http://ejournal.unp.ac.id/index.php/tingkap/article/viewFile/2799/2346

Syamsir, S. (2014). Public Service Motivation and Socio Demographic Antecedents among Civil Service in Indonesia. BISNIS \& BIROKRASI: Jurnal Ilmu Administrasi dan Organisasi, 21(1), 1-8. http://journal.ui.ac.id/index.php/jbb/article/viewArticle/4038/3114

Syamsir, S. (2015). Public Service Motivation among Indonesian Employees: a Critical Review Toward the Psm Theory. European Journal of Social Sciences Education and Research, 5(1), 133-142. http://journals.euser.org/files/articles/ejser_sep_dec_15/Syamsir.pdf.http://d oi.org/http://dx.doi.org/10.26417/ejser.v5i1.p133-142

http://journals.euser.org/index.php/ejser/article/view/778.

B Baiyulis, S Syamsir, J Jumiati. 2018. Pengaruh Kepuasan Kerja Terhadap Kinerja Perangkat Nagari Dalam Pengelolaan Keuangan Nagari di Kecamatan Sungai Tarab dan Salimpaung. Journal Of Education on Social Science (JESS) 2(2),73-84.

\section{Perundang-undangan}

Undang-undang Nomor 32 tahun 2004 tentang Pemerintahan Daerah

Undang-Undang Nomor 6 Tahun 2014 tentang Desa

Peraturan Bupati Tanah Datar No 11 Tahun 2014 tentang Pedoman Pengelolaan Keuangan Nagari

Peraturan Daerah Kabupaten Tanah Datar No 4 Tahun 2008 tentang Nagari

Peraturan Mentri Dalam Negri No 113 Tahun 2014 tentang Pengelolaan Keuangan Desa 


\section{Sumber Berita}

Dwi. 2017. Proyek Jalan Koto Panjang Tanah Datar, Diduga Berbau Korupsi. Batusangkar. http://www.sumbartoday.com/proyek-jalan-koto-panjangtanah-datar-diduga-berbau-korupsi. Sumbar Today. 